\title{
Assessing the Potential Presence and Impact of Nile tilapia, Oreochromis niloticus (Pisces: Cichlidae; Linnaeus 1758) in Mutukutuku Reservoir in Solwezi, Zambia
}

Arthertone Jere ${ }^{1}$, Lackson Chama $^{2}$ and Siachoono Stanford ${ }^{2}$

1. Ministry of Fisheries and Livestock, Department of Fisheries, Extension Services, Solwezi 110118, Zambia

2. Department Zoology and Aquatic Science, School of Natural Resources, The Copperbelt University, Kitwe 21692, Zambia

\begin{abstract}
Invasive alien species are one of the greatest threats to biodiversity and ecosystem globally, affecting delivery of ecosystem goods and services, and consequently human well-being. Oreochromis niloticus is one of the most highly successful invaders of aquatic ecosystems with competitive characteristic advantages over indigenous species. The aim of this study was to investigate the potential presence and impact of $O$. niloticus on Mitukutuku fishery. The study was undertaken using fisheries independent surveys for the period of 2 months. Fish identification key and gel electrophoresis identification methods were also used to confirm presence of $O$. niloticus and also possible hybridization with indigenous congeneric species. Fisheries dependent survey was conducted with fishers and traders to further assess presence of the invasive species and its impacts on their catches and socio-economic well-being. A total of 32 Oreochromis hybrids species and 19 of $O$. niloticus were found in the reservoir. This confirmed a higher proportion of $O$. niloticus in the reservoir. Results from interviews of fishers and traders revealed catch per unit effort of $O$. hybrids and $O$. niloticus to be higher compared to that of indigenous congeneric species. Similarly, fish traders confirmed that income for the fish sales increased from $5 \%$ in March to 7\% in August. Overall, these results suggested that O. niloticus does not only exist in Mitukutuku reservoir, but also hybridizes with native species and dominates the entire stretch of the reservoir threatening loss of biodiversity and aquaculture breeding programme. There is need for restricting culture of $O$. niloticus in Zambia.
\end{abstract}

Key words: Aestivate, congeneric species, invasive, impact, Mitukutuku, reservoir, Solwezi, Zambia.

\section{Introduction}

\subsection{Background to the Problem}

Tilapias of the genus Oreochromis are a popular species for aquaculture in several regions of the world. This is largely because they host several characteristics that make them most suitable for aquaculture (i.e., including its rapid growth rate, general hardiness, ability to efficiently utilize organic wastes and ease of breeding). However, these characteristics make them a successful invader of other species as this gives them a competitive advantage to survive well and dominate natural waterways and reservoirs. As a consequence,

Corresponding author: Arthertone Jere, $\mathrm{PhD}$ candidate, research field: fisheries ecology. some species such as Oreochromis niloticus are rated among the 100 most invasive species in the world (Global Invasive Species Database, 2015).

Tilapia is highly adaptable and has been reported to aestivate (maintain a prolonged state of inactivity) in wet river sands in semi-arid and arid regions of their native African habitat. This enables them to survive in dry river pools and rapidly recolonize areas when dry periods end (Schnell and Seebacher, 2008). Under adverse conditions such as drought, tilapia can switch from a normal growth and maturation rate (where fish first breed at two or three years old and at a size of 25-35 cm), to stunted populations where fish mature at very small sizes $(9-10 \mathrm{~cm})$ and breed at only a few months old (Ganie, et al., 2013). This simply suggests 

Linnaeus 1758) in Mutukutuku Reservoir in Solwezi, Zambia

that, tilapia can produce within considerable amount of time in a year with favorable conditions. Tilapia also provides parental care, where the female brood eggs and young in her mouth to protect them from predation. Thus, these traits and behaviors mean tilapias have the capacity to rapidly increase in numbers and dominate waterways (Bilgrami, 1992).

The history of fish culture in Zambia includes collection of potential breeders from the natural waters (rivers and lakes). Many large fisheries are preferred as potential sources for breed stock for most aquaculture breeding programmes. Fish introductions are categorized into two aspects, introduction of non-indigenous species which are not native to the fishery for the purpose of improved production and of indigenous species for replenishing of depleted stocks. Introduction in Zambia was first done in the early 1940 when bluegill (Lepomis macrochirus), tench (Tinca vulgaris), spotted bass (Micropterus punctualatus) and rainbow trout (Salmo gairdneri), were introduced at the government fish farm in chilanga (Kenzu and Mazingaliwa, 2002). Oreochromis niloticus in Zambia was introduced towards the end of 1980s by a fish farmer whose fish later escaped into the Kafue River (Kenzu and Mazingaliwa, 2002).

Mitukutuku reservoir is one of the most important natural water reservoirs of Indogangetic plains, originating from an underground spring. Recently, an embankment was established near the end of the reservoir to increase the water capacity. The Department of Fisheries (DoF) in 2008 stocked the reservoir with fingerlings of Oreochromis machrochir, Oreochromis andersonii and Tilapia rendalli to replenish deliplited fish stocks and promote species of economic value to the local community (DoF, 2008).

This study reviewed available information on the current distribution of Oreochromis niloticus in Zambia and assessed its potential presence and impacts on native species and local community in small fisheries such as the Mitukutuku reservoir.

\section{Material and Methods}

\subsection{Description of the Study Area}

The study was undertaken in Mitukutuku reservoir, located within Solwezi, the district capital for Northwestern province in Zambia. The areais located approximately $20 \mathrm{~km}$ from the Solwezi town (latitude $26^{\circ} 20^{\prime} 23.70^{\prime \prime} \mathrm{E}$ and longitude $12^{\circ} 14^{\prime} 21.31^{\prime \prime} \mathrm{S}$ ). It has a water surface area of about $1,473 \mathrm{~km}^{2}$, with numerous fish landing sites.

The justification of the study site (Fig. 1) is that the fishery provides economic importance to the local communities as a livelihood and a source of fish breed stock for aquaculture breeding programme by the Department of Fisheries in Solwezi. Besides, there are no studies that have been done to investigate the presence of $O$. niloticus in this fishery.

\section{Research Design}

The study was largely centered on establishing the potential presence and impacts of Oreochromis niloticus on both native species and on the socio-economic wellbeing of the local community.

Firstly, the potential presence of Oreochromis niloticus was ascertained. To do this, fisheries independent sampling method was used and it involved the quantitative sampling method using gill nets to catch fish from several sampling points. Sampling was conducted from 4 distinct habitats (spring source, vegetative thicket point, open poor and spill way) of the reservoir for the period of 2 months, i.e. one (1) month in rain season (March) and another (mid-July to mid-August) in dry season fortnightly. Sampling was done for three (3) consecutive days in one week in each distinct habitat, from which gill nets settings were set three (3) times in each site for each gear ranging from one to three and half inches mesh sized nets. This gave a total of nine sampling times. 

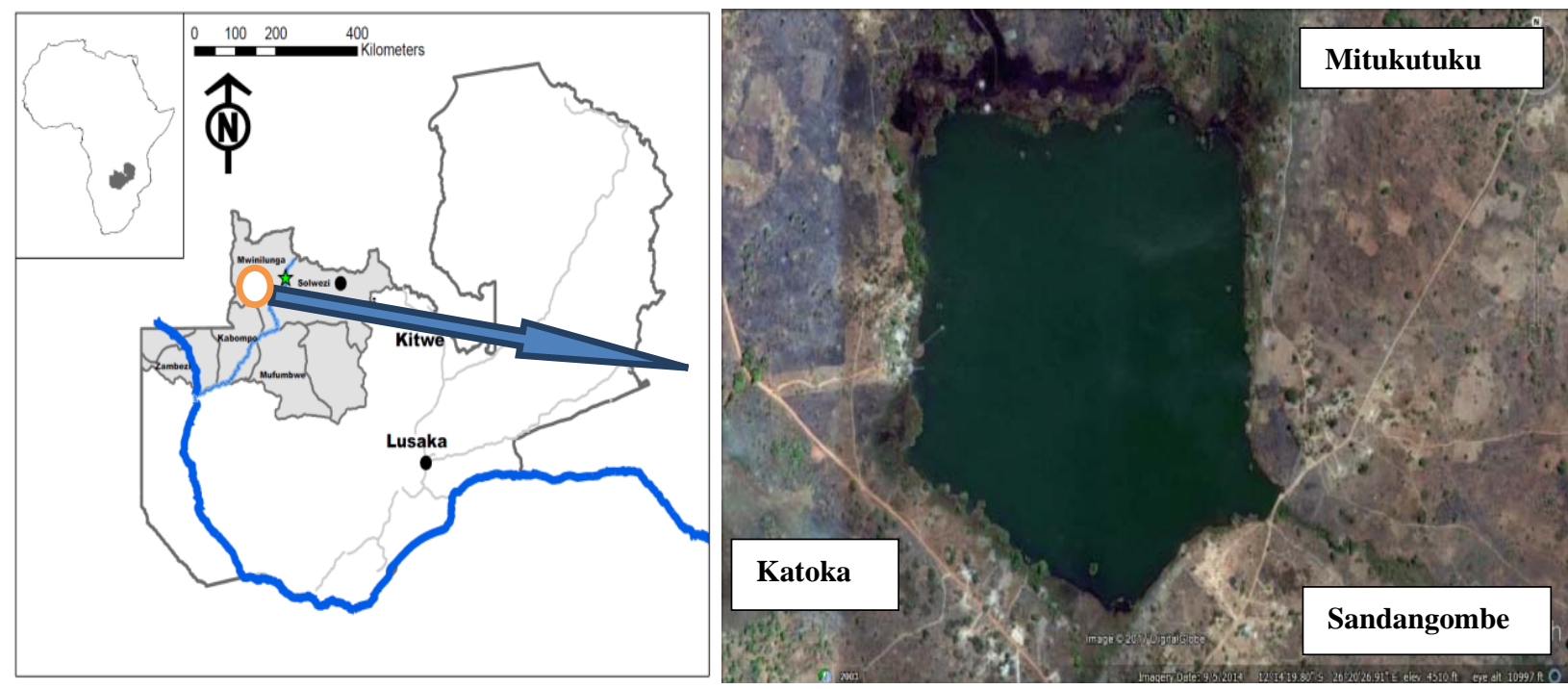

Fig. 1 Location map of the study area, Mitukutuku reservoir.

Source: Google maps, 2017.

Secondly, the impact of $O$. niloticus on native species was established. To do this, again, fisheries independent sampling technique was used to assess the ichthyofauna which included: quantitative sampling technique (gill nets) and semi-quantitative sampling (Seine nets, D nets, Pole and line) during sampling event. Sampling was conducted in the early mornings and evenings because in these hours all the fish were fresh and easy to identify before spoilage takes place both from sampling points and the catches from artisanal fishers.

Thirdly, the impact of $O$. niloticus on the socio-economic wellbeing of the local community was established. To do this, fisheries dependent catch recording was used to determine patterns in resource utilization in order to understand the fishery dynamics and socio-economic importance to community livelihoods. These techniques rely on obtaining catch and effort information directly from the fishermen such as sale (earnings) of $O$. niloticus catches in relation to native congeneric species catches. Fisheries dependent surveys therefore include: catch and effort surveys through semi-structured interview (Annex i) with fishers and traders being administered. A total of ten (10) persons from the surrounding area who are recognized as fishing experts and five (5) fish traders in local market area were selected with the aid of local authorities who identified them as experienced and having been in the industry for more than a decade following the approach of Schwanck (1995). This was to help confirm the presence and changes in catch-per-unit effort of $O$. niloticus and native species in the reservoir over time.

\subsection{Data Analysis}

To establish the potential presence of Oreochromis niloticus in the reservoir, descriptive analysis with Microsoft excel 2007 (Summation and percentages package) was used to calculate fish samples collected from all the sampling sites. The fish samples were identified using the fish identification key from reference literature (Jayaram, 1981) before subjecting to software package for analysis.

To establish the proportion of presence of Oreochromis niloticus, relative abundance (RA) formula adopted from Lakra et al. (2010), was used to calculate contribution of each individual species to the overall fish catch at each sampling site. To achieve this, Microsoft excel 2007 (Average and Percentages package) was then used to compute their relative abundance of the particular fish species from each sampling site. One-way ANOVA under SPSS 16 version was thereafter used to test the difference 
between the means of abundance of individual taxa from different sample groups.

Impact of $O$. niloticus on indigenous congeneric species in the reservoir was established using gel electrophoresis method for identification of possible hybrids (Buell et al., 1978). This method separates and analyzes macromolecules (DNA and protein) and other fragments based on their size and charge, agar gel solution was fitted in an electrophoresis chamber after which electric current of 100 volts was passed through the solution for identification. Catch information was then descriptively analyzed with Microsoft excel 2007 (Percentage and Summation Package) to get difference in catch sizes from sampling sites.

To establish the impact of O. niloticus on local people especially fishers and traders, respondents information was collated via spreadsheets using Microsoft excel 2007 (Summation and percentage packages), of which income from selling of fish, people involvement in fishing and catch-per-unit-effort were calculated.

\section{Results}

\subsection{Potential Presence of Oreochromis niloticus in} Mitukutuku Reservoir

A total of 306 fish samples representing 18 families (Table 1) were captured from all the sampling sites. The number of fish samples captured per sampling event in each survey period ranged from 200 to 106 in March and August respectively. The invasive species
Oreochromis niloticus (Fig. 2) was found in the entire extent of the reservoir.

\subsection{Proportion of Presences of $O$. niloticus in} Mitukutuku Reservoir

A considerable composition of Oreochromis niloticus constituting 6\% was found in the total catch. This indicates a higher significance $(F=56.33$; $\mathrm{df}=1$; $p<0.05$ ) in terms of dominance in the reservoir than other native species (Oreochromi macrochir 4\% and Oreochromis andersonii 5\%; Table 1). Relative abundance of Oreochromis niloticus was higher $(F=$ 5.6 ; $\mathrm{df}=6 ; p<0.05$ ), showing $5 \%$ on average than that of Oreochromis congeneric species (Fig. 3).

\subsection{Impacts of O. niloticus on Native Congeneric Species in Mitukutuku Reservoir}

The results of suspected Oreochromis hybrids and native Oreochromis genera were confirmed using the gel electrophoresis methods. The species contributed to an average of $12.6 \%$ of the total fish caught, with features of Oreochromis niloticus and Oreochromis andersonii (Fig. 4). Oreochromis hybrids contributed to the highest catch by $4 \%$ more than other Oreochromis congeneric species. The variability in fish catches was high in all study sites. It was $4 \% \pm 11 \%$ for Oreochromis machrochir, $4 \% \pm 7 \%$ for Oreochromis niloticus, $6 \% \pm 22 \%$ for Oreochromis hybrids and $2 \% \pm 4 \%$ for Oreochromis andersonii (Fig. 5).

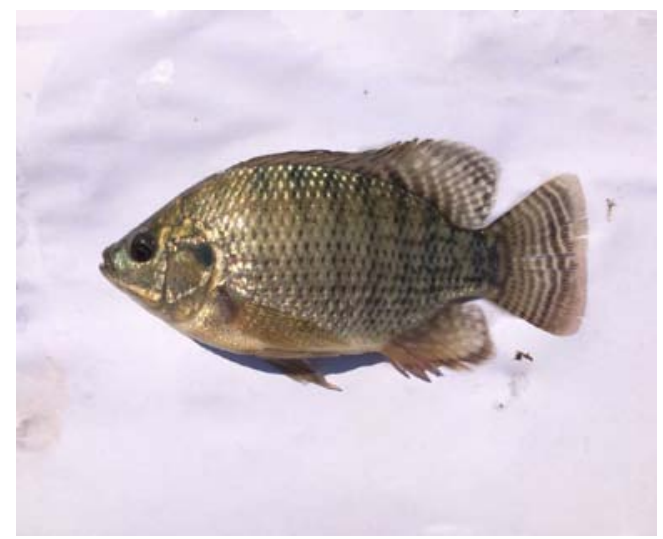

Fig. 2 Nile tilapia, Oreochromis niloticus captured from Mitukutuku reservoir. 

Linnaeus 1758) in Mutukutuku Reservoir in Solwezi, Zambia

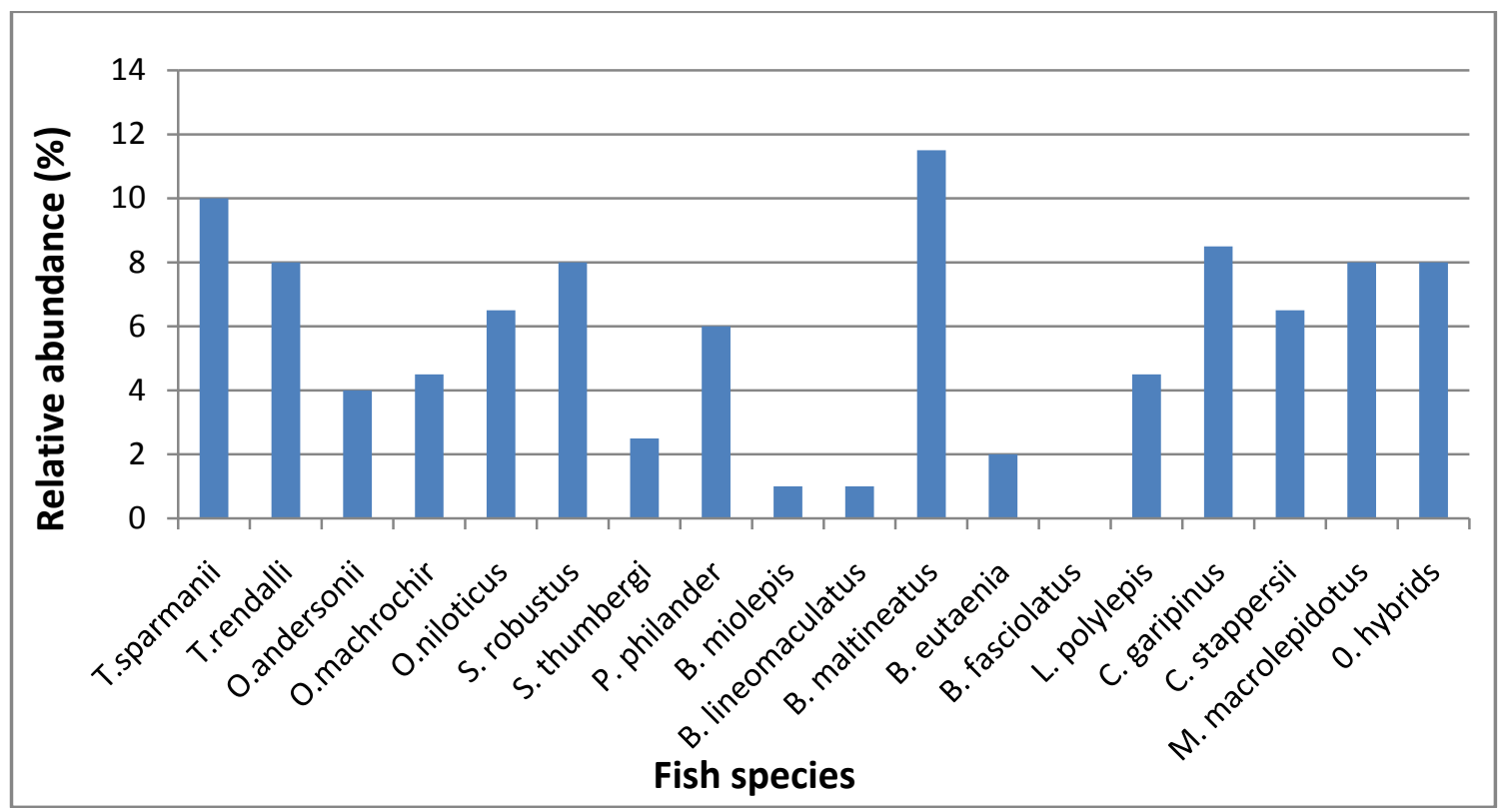

Fig. 3 Average relative abundance of the fish collection for March and August 2016 at Mitukutuku reservoir.

Fig. 4 Oreochromis hybrid [O. niloticus X O. andersonii] collected from Mitukutuku reservoir.
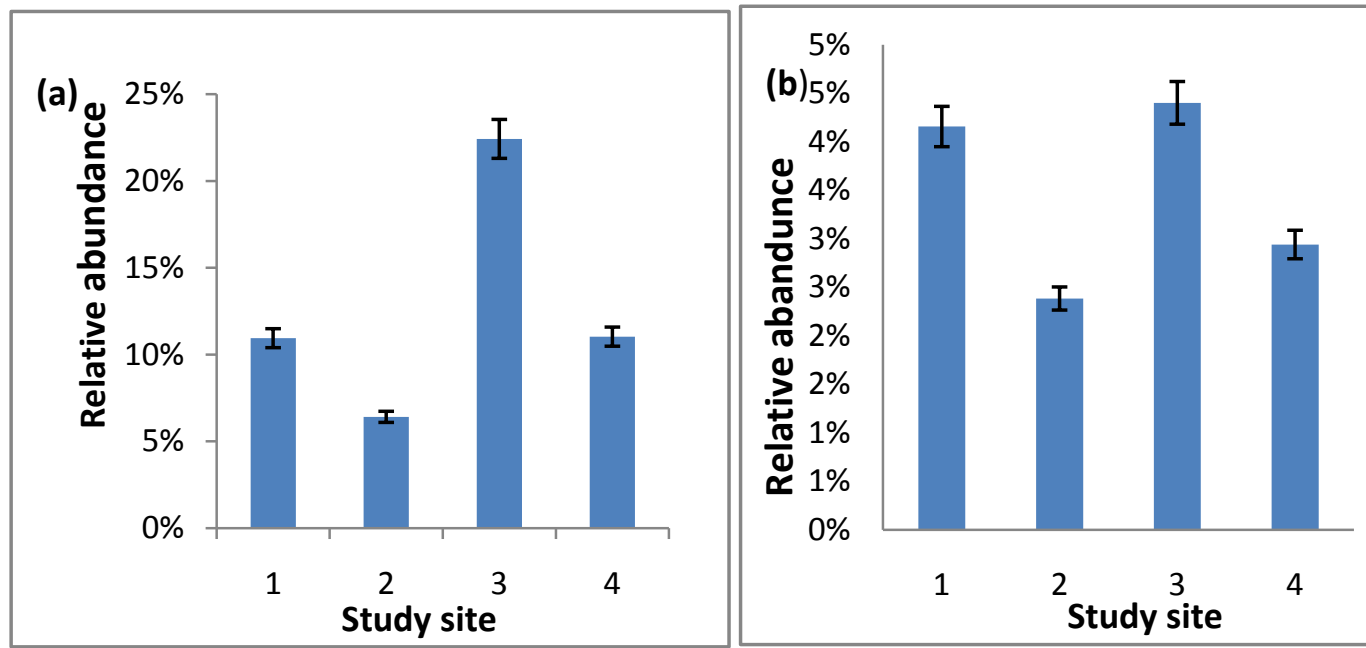

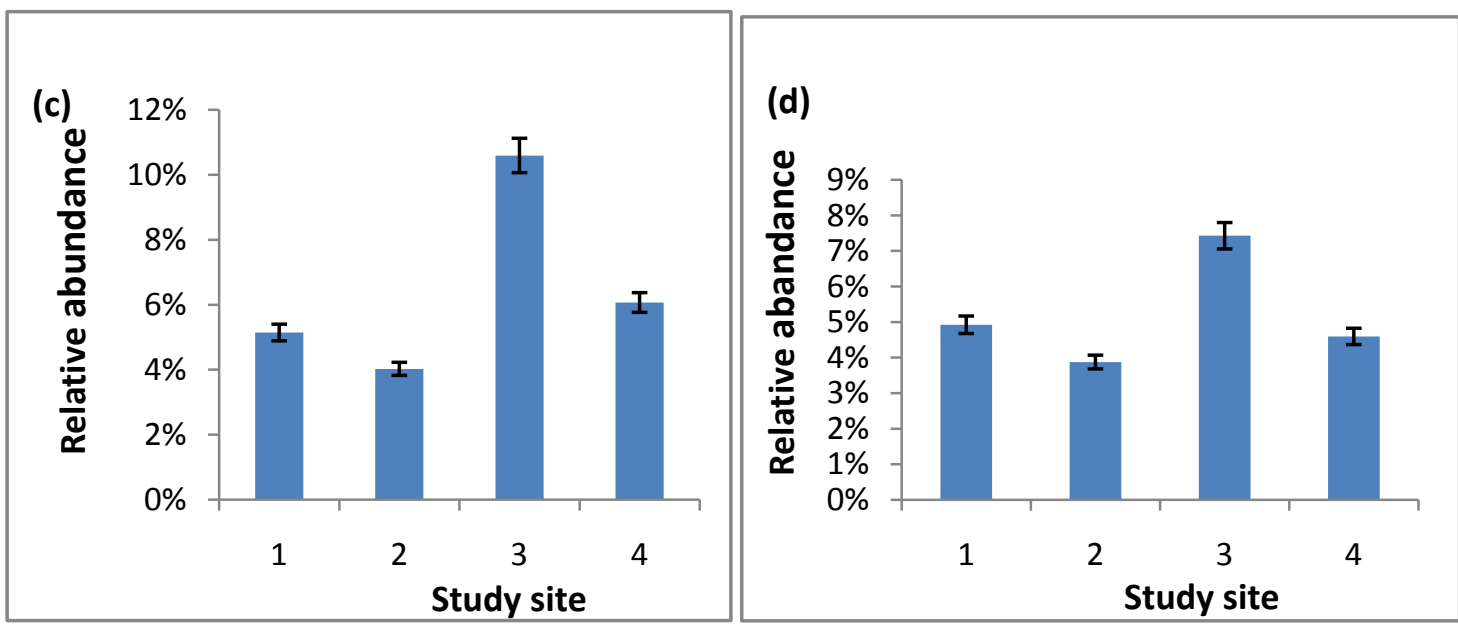

Fig. 5. The error bars represent $95 \%$ confidence level of the relative abundance for fish species caught (a) Oreochromis hybrid, (b) Oreochromis macrochir, (c) Oreochromis niloticus and (d) Oreochromis andersonii during the March and August survey in four (4) sites.

Table 1 Species richness, Relative Abundance of fish collected from the Mitukutuku reservoir at four study sites (S1, S2, S3, and S4) for March \& August, 2016.

\begin{tabular}{|c|c|c|c|c|c|}
\hline Specie & Family & S1 (RA\%) & S2 (RA\%) & S3 (RA\%) & S4 (RA\%) \\
\hline Tilapia sparmanii & Cichilidae & 12 & 9 & 6 & 21 \\
\hline Tilapia rendalli & Cichilidae & 8 & 12 & 2 & 11 \\
\hline Oreochromis macrochir & Cichilidae & 4 & 2 & 4 & 3 \\
\hline Oreochromis niloticus & Cichilidae & 5 & 4 & 11 & 6 \\
\hline Orechromis andersoniiw & Cichilidae & 5 & 4 & 7 & 5 \\
\hline Serranochromis robustus & Cichilidae & 4 & 0 & 2 & 0 \\
\hline Serrgonochromis thumbergi & Cichilidae & 3 & 1 & 3 & 5 \\
\hline Pseudocrealabrus philander & Cichilidae & 14 & 22 & 15 & 22 \\
\hline Barbus miolepis & Cyprinidae & 4 & 3 & 5 & 2 \\
\hline Barbus lineomaculatus & Cyprinidae & 3 & 4 & 1 & 4 \\
\hline Barbus maltineatus & Cyprinidae & 3 & 2 & 2 & 1 \\
\hline Barbuseutaenia & Cyprinidae & 4 & 5 & 7 & 2 \\
\hline Barbus fasciolatus & Cyprinidae & 0 & 2 & 0 & 2 \\
\hline Labeobarbus polylepis & Cyprinidae & 7 & 11 & 6 & 2 \\
\hline Clarias garipinus & Clarridae & 2 & 0 & 2 & 0 \\
\hline Clarias stappersii & Clarridae & 0 & 1 & 2 & 1 \\
\hline Marcusenius macrolepidotus & Mormiridae & 10 & 10 & 2 & 2 \\
\hline Oreochromis hybrids & Cichilidae & 11 & 6 & 22 & 11 \\
\hline
\end{tabular}

* Taxonomic status adapted from Talwar and Jhingran (1991).

\subsection{Potential Impact of O. niloticus on Socio-Economic Well-Being of Local Community at Mitukutuku}

The fishermen involved in daily fishing represented 28\% in March and 14\% in August (Fig. 6a), according to the village fisher register. Five fish traders interviewed indicated that the household income was $(7 \% \pm 4 \%)$ in Katoka, $(3.2 \% \pm 3 \%)$ at Sandangombe and $(4.3 \% \pm 4 \%)$ at Mitukutuku (Fig. 6b). Catch survey result mean showed 54\% in March and 36\% for August (Fig. 7). Oreochromis hybrids and $O$. niloticus were reportedly to increase in catch per unit effort together with Pseudocrealabrus philander and Tilapia rendalli (Fig. 8). Fishermen also observed a decline in the indigenous congeneric species (Fig. 9). 
Assessing the Potential Presence and Impact of Nile tilapia, Oreochromis niloticus (Pisces: Cichlidae; 391 Linnaeus 1758) in Mutukutuku Reservoir in Solwezi, Zambia
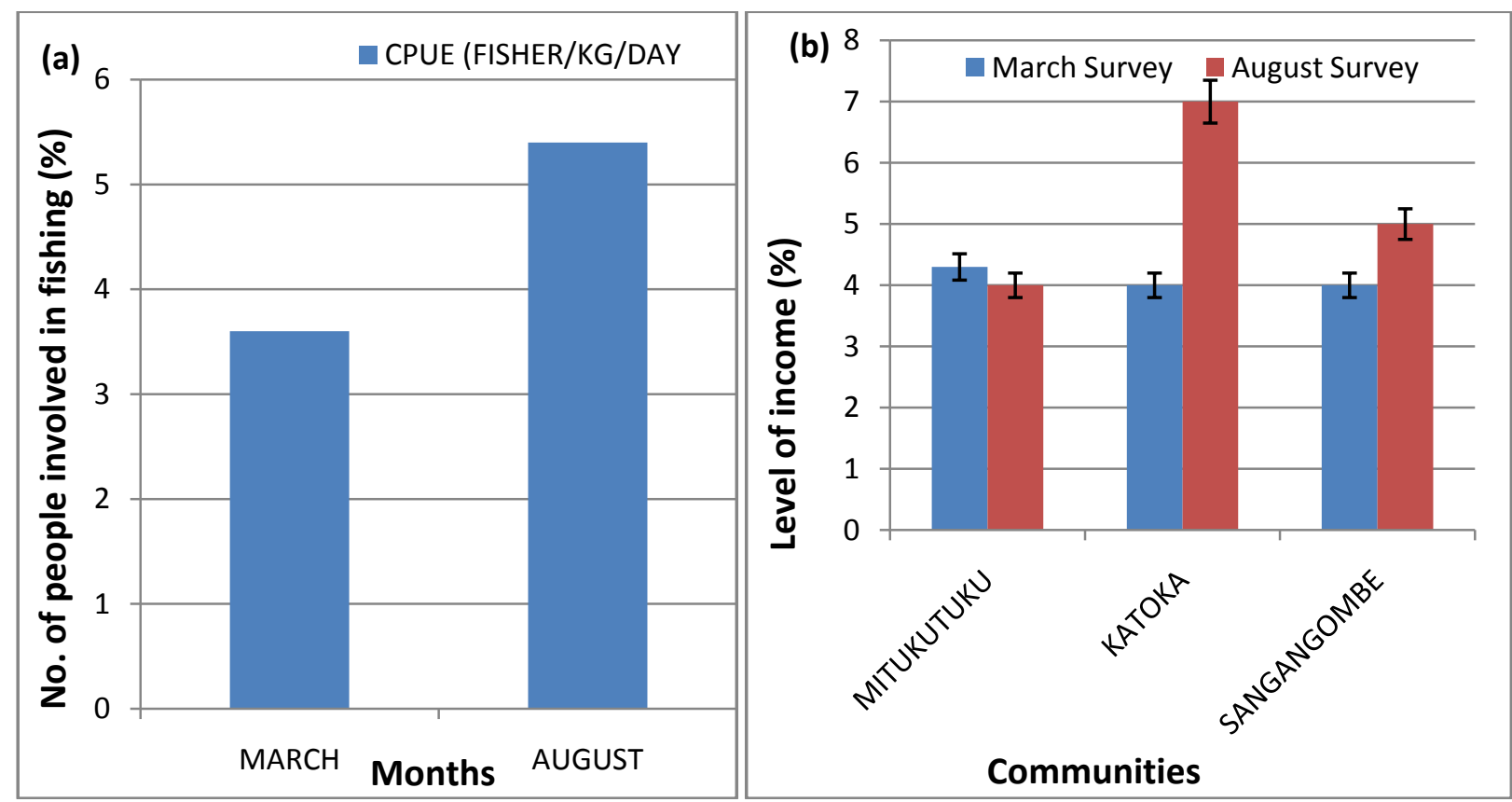

Fig. 6 Socio-economic survey. (a) Population involvement in day-night fishing activities; (b) the error bars represent 95\% confidence level of average level of income raised from fish catch at each community per month during the survey.

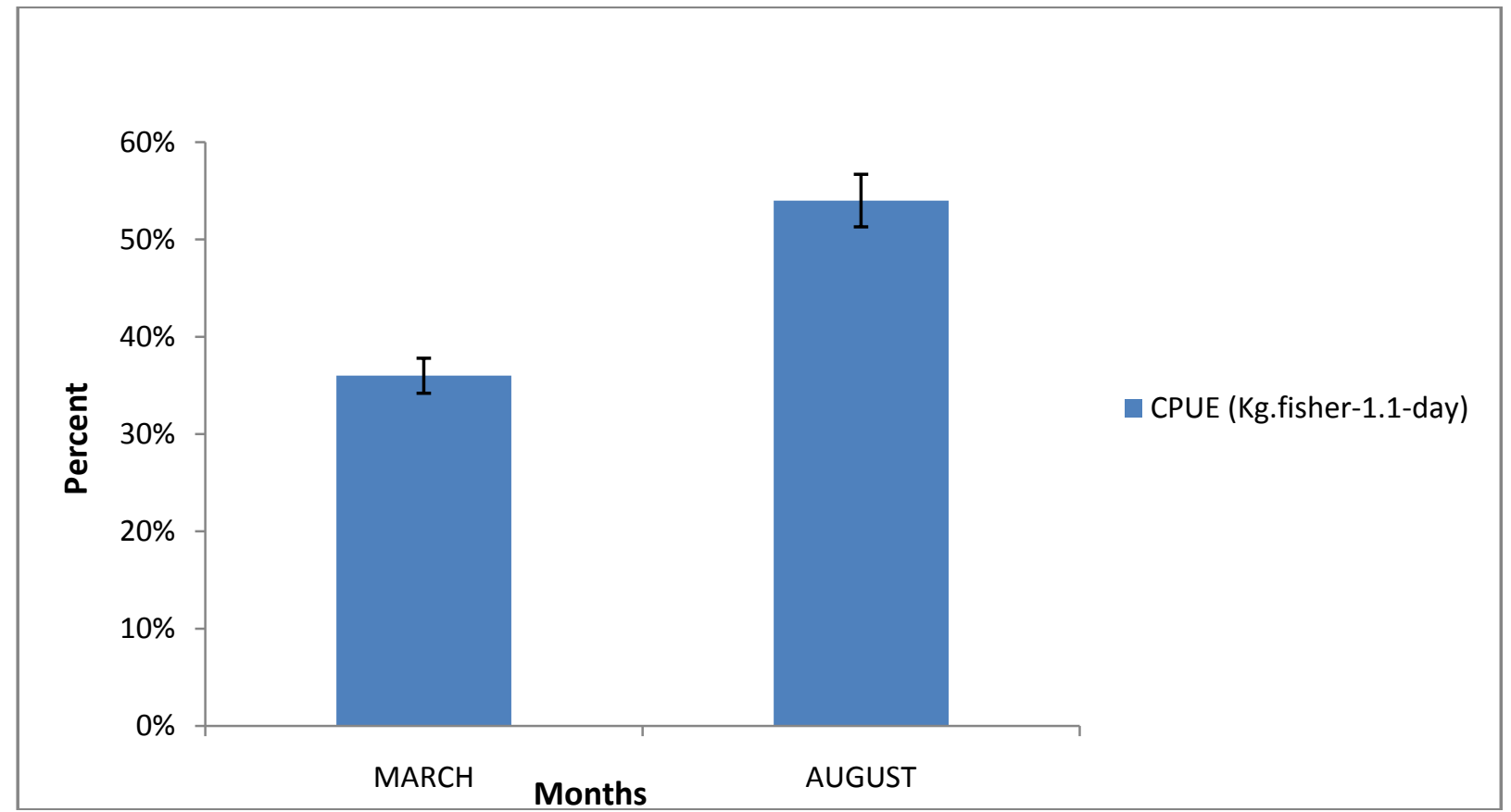

Fig. 7 The error bars represent $\mathbf{9 5 \%}$ confidence level of Mean Catch per unit effort (CPUE) for two survey months at Mitukutuku reservoir. 


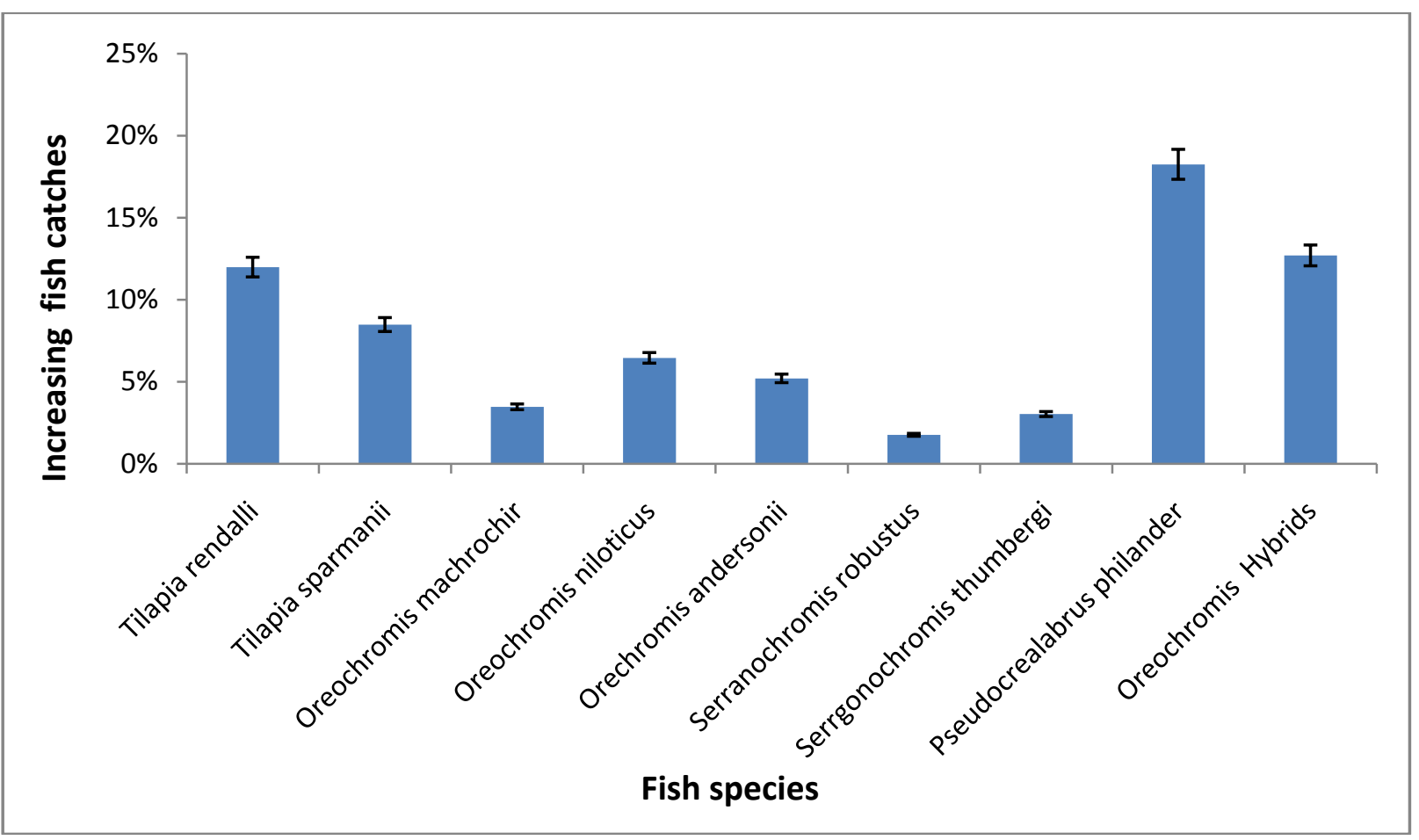

Fig. 8 The error bars represent $95 \%$ confidence level of increasing fish species observed by the interviewed local fishermen.

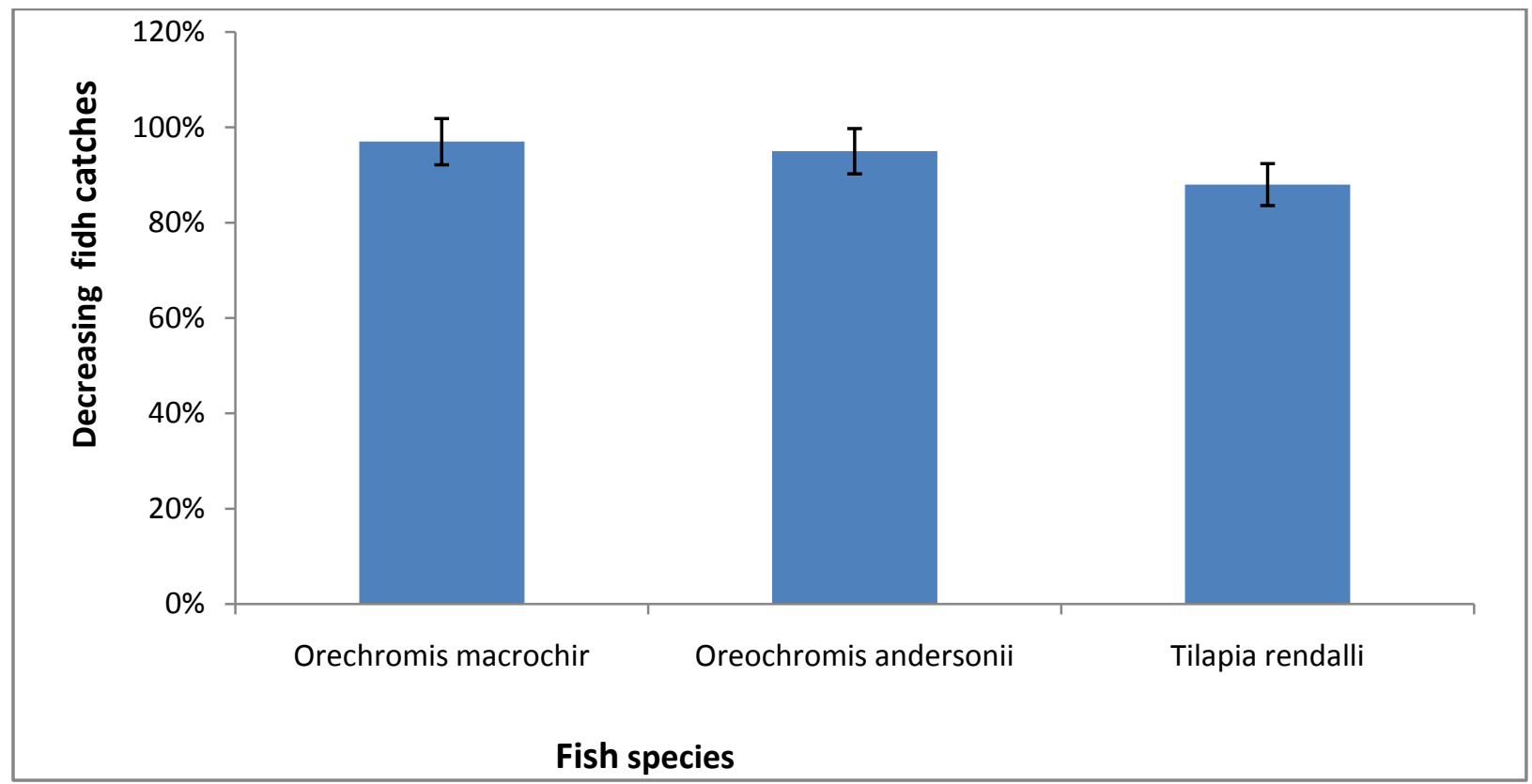

Fig. 9 The error bars represent 95\% confidence level of decreasing fish species observed by the interviewed local fishermen.

\section{Discussion}

\subsection{Potential Presence of Oreochromis niloticus in the Reservoir}

This study has revealed that $O$. niloticus is present in the Mitukutuku reservoir. Thomas (2007) in his report indicated that, promotion of Oreochromis niloticus in Solwezi, Northwestern province of Zambia was to improve aquaculture production among small scale farmers. To this effect many farmers in the region are culturing $O$. niloticus extensively that includes the surrounding areas of the Mitukutuku reservoir. 
Generally, this could suggest that $O$. niloticus could have found itself in the reservoir through possible escape from nearby fish ponds. Similar situation is listed, where Nile perch was unofficially introduced into Lake Victoria in year 1954, when the fish species from Lake Albert were illegally released at Jinja in Uganda and now has dominated Lake Victoria (Balirwa, 1992). This means that O. niloticus could have been stocked unnoticed and or through escapes from fish farmers around Mitukutuku reservoir. This scenario is common in many countries where invasive species have been introduced unintentionally, but eventually such species get established in the new ecosystems. However, in certain introductions it has been through use of fish species as biological controls to mitigate challenge of either aquatic weeds or pastes, but then result in invasion and become more dominant than native species. Therefore, although there is an urgent need to promote fish farming, it remains critical that this process is supported by research to identify the appropriate fish species to use in specific area. This will help to reduce the uncontrollable spread of invasive species as in the case of $O$. niloticus.

\subsection{Proportion of Presence of O. niloticus in the Reservoir}

Results of this study showed abundance of $O$. niloticus in the fishery and the presence was in all sampled sites, suggesting that $O$. niloticus is distributed throughout the reservoir. The relative abundance average results showed $O$. niloticus is significantly higher than $O$. andersonii and O. macrochir. This clearly implies that $O$. niloticus is more dominant than indigenous congeneric species. Similarly, O. niloticus was shown to spread up to stretch of $250 \mathrm{~km}$ after escaping from the private farmer in Mazabuka district into the Kafue River and dominated the entire (250 km) stretch of the river within a short period (Bbola et al., 2014). This was also noted in Lake Victoria when Nile perch, Latesniloticus dominated more than the native Haplochromine cichlids (Witte et al., 1992). Generally, this implies that the competitive characteristic advantage of $O$. niloticus over indigenous congeneric species makes them have higher dominance and wide distribution. Therefore, this explains the increase of $O$. niloticus in the reservoir at the expense of the indigenous congeneric species.

\subsection{Impact of O. niloticus on Native Species at Mitukutuku Reservoir}

Our findings have also revealed that $O$. niloticus was found to hybridize with closely related indigenous congeneric species, particularly $O$. andersonii. Higher fish catches of Oreochromis hybrids were observed from all sampled sites and contributed significantly to the overall catch of the Oreochromis congeneric species. The Oreochromis hybrids had a combination of characteristics of O. niloticus and O. andersonii and were in different stages of development. Similarly, other studies (Barel et al., 1983) have shown that the introgression of $O$. niloticus alleles into the indigenous Oreochromis congenerics, showed the resultant hybrids as being non-sterile and were able to backcross with each other and with $O$. macrochir and $O$. andersonii, facilitating gene mixing between the indigenous congeneric that does not otherwise frequently hybridize in sympatry (Schwank, 1995). This generally suggested that facilitated hybridization will likely have a major impact on the conservation of indigenous congeneric as they are likely to be eradicated from the reservoir and replaced by a mixture of introgressive hybrids.

Taken at face value, the reduction in fish catches of $O$. andersonii and O. macrochir from the reservoir as reported by fishermen, could have led to the establishment of the non-native species at the expense of the indigenous congeneric species. The probable explanation for this is the potential of $O$. niloticus to hybridize with other indigenous congeneric species. This is then followed by the eradication of hybrids leaving only pure $O$. niloticus strains, (Schwanch, 1995). Therefore, the takeover is mostly preceded by a 
period of introgressive hybridization with native species (Schwanch, 1995). In this case, O. niloticus' ability to hybridize other species explains the observed increase in its hybrids proportion compared to the indigenous congeneric species in the reservoir.

\subsection{Impact of $O$. niloticus on Socio-Economic Wellbeing of Local Community}

Food security and nutritional needs of people in local communities are more important for their well-being, this then demonstrates a concern that goes beyond the genetic and potential ecological impacts (Sala et al, 2000). Musumali et al. (2009), pointed out that fish is an important food for over 400 million Africans, contributing substantially to protein, mineral and other micronutrients to their diets. Zambia is not an exception. Fish provides an estimate of about $40 \%$ of animal protein intake to most Zambians (FAO, 2012). The protein in diets plays an important role in the food and nutrition especially in urban and rural poor people of Zambians living with HIV and AIDS (Musumali et al., 2009)

Taking the case of Mitukutuku reservoir, fishing is one of the most important income generating ventures for the local communities. The results from the interviews with fish traders revealed high level of income raised from the fish sales in March compared with August survey. Although, the number of people involved in fishing according to the fisher register in March survey was also higher than in August, fishing activities were reported to have taken place in both periods of the survey. Generally, these results suggest that fishing provides income almost all year round to youth, women and men who can not find other sources of income.

Furthermore, fishermen interviewed also reported a reduction in the catch-per-unit-effort of the natives Oreochromis species, which are widely favored by most people. Respondents also observed high catches-per-unit-effort of $O$. niloticus and Oreochromis hybridsthan native Oreochromis species, which contributed to the increase in income from the sales. Similar finding of the spectacular introduction of brush-tailed possums (Trichosurus vulpecula) to New Zealand resulted in serious defoliation, but was also highly profitable for the "eco-friendly" fur industry (at least US\$ 20 million annually in exports; Poff and Allan, 1995). Generally, this could suggest that high fish catches observed by fishermen led to increased income for the local people. Consequently, the loss of native species can lead to loss of genetic diversity necessary for future food security and poverty reduction. Food security entails the access to enough amounts of safe, nutritious and quality food (FAO, 2012). For communities in Mitukutuku, fishing is an important, if not the most vital, activity by which local families meet their food needs and achieve economic security. Anything that disturbs these important sources of nutrition and economic livelihood is likely to embolden poverty and imperil food security. Therefore, the results suggested that $O$. niloticus has direct (as increase in prices of native species) and indirect (use of illegal fishing methods) negative impact on the local community of Mitukutuku reservoir.

\section{Conclusion/Recommendation}

This study has nevertheless revealed that $O$. niloticus species was present in the entire stretch of reservoir extent. The local fishermen and traders confirmed the presence of the $O$. niloticus in the reservoir. They have reported an increase in catches of $O$. niloticus and associated this increase with reduction in catches of native $O$. macrochir and $O$. andersonii. Moreover, fishermen observed $O$. hybrids with the combined characteristics of $O$. niloticus and indigenous congeneric species. Fish traders from local area also confirmed the increased demand for native species that possibly stimulated fishing effort using various fishing methods that included illegal methods. Therefore, this further poses serious threats to fish biodiversity and decline to the native Oreochromis species through 

Linnaeus 1758) in Mutukutuku Reservoir in Solwezi, Zambia

hybridization and trophic overlap in the reservoir.

Recommendations include restricting culture of $O$. niloticus, although exclusion is preferred when it is possible in areas that it has been introduced. Hence, suitable management and control methods should be found. Such information could contribute to the development of management plans aimed at minimizing other possible impacts of this potential invasive species. There is need for increased funding towards research in the culturing of indigenous species and creation and also establishment of a gene bank for sustainable aquaculture programmes. Moreover, awareness of the implications concerning this invasive species should be generated among scientists, legislators, farmers, fishermen and the general public to provide for the rigorous application of such regulatory measures.

\section{References}

[1] Balirwa, J. S. 1992. "The Evolution of the Fishery of Oreochromis niloticus (Pisces: Cichlidae) in Lake Victoria.” Hydrobiologia 232: 85-9.

[2] Barel, C. D. N., Van Oijen, M. J. P., Witte, F., and Witte-Maas, E. L. M. 1983. “An Introduction to the Taxonomy and Morphology of the Haplochromine from Lake Victoria." Netherland Journal of Zoology 27: 333-89.

[3] Bbole, I., Katongo, C., Deines, A. M., Shumba, O., and Lodge, D. M. 2014. "Evidence of Hybridization between Non-indigenous Oreochromis Species in the Lower Kafue River and Its Potential Impacts on Fishery." Journal of Ecology and the Natural Environment 6 (6): 215-25.

[4] Buell, G. N., Wickens, M. P., Payvar, F., and Schimke, R. T. 1978. "Synthesis of Full Length cDNAs from Four Partially Purified Oviduct mRNAs.” The Journal of Biological Chemistry 253 (7): 2471-82.

[5] DoF. 2008. District Annual Report. Department of Fisheries in Solwezi Northwestern Province, Zambia. Registry. Solwezi.

[6] FAO. 2012. The World Fisheries and Aquaculture 2012. Rome, Italy.

[7] Ganie, M. A., Mehraj, D. B., Mohd, I. K., Muni, P., and
Balkhi, M. H. 2013. "Invasion of the Mozambique Tilapia, Oreochromis mossambicus (Pisces: Cichlidae; Peters, 1852) in the Yamuna River, Uttar Pradesh, India.” Journal of Ecology and the Natural Environment 5 (10): 310-7.

[8] Global Invasive Species Database. 2015. "Oreochromis niloticus.” Accessed March 24, 2016. http://www.issg.org/database/species/ecology.asp.

[9] Jayaram, K. C. 1981. Fresh Water Fishes of India-Hand Book. Calcutta: Zoological Survey of India, p. 225.

[10] Lakra, W. S., Sarkar, U. K., Kumar, R. S., Pandey, A., Dubey, V. K., and Gusain, O. M. 2010. "Fish Diversity, Habitat Ecology and Their Conservation and Management Issues of a Tropical River in Ganga Basin, India.” Environmentalist 30 (4): 306-19.

[11] Poff, N. L., and Allan, J. D. 1995. "Functional Organization of Stream Fish Assemblages in Relation to Hydrological Variability.” Ecology 76: 606-27.

[12] Kenzo, U., and Mazingaliwa, K. 2002. Field Guide to Zambia Fishes, Plankton and Aquaculture. Japan: International Cooperation Agency.

[13] Sala, O. E., Chapin, F. S., Armesto, J. J., Berlow, E., Bloomfield, J., Dirzo, R., Huber-Sanwald, E., Huenneke, L. F., Jackson, R. B., Kinzig, A., et al. 2000. "Biodiversity-Global Biodiversity Scenarios for the Year 2100.” Science 287: 1770-4.

[14] Schnell, A., and Seebacher, F. 2008. "Can Phenotypic Plasticity Facilitate Geographical Expansion of the Tilapia Oreochromis mossambicus?” Physiological and Biochemical Zoology 81: 733-42.

[15] Schwank, E. J. 1995. "The Introduction of Oreochromis niloticus Is Spreading on the Kafue Floodplains, Zambia." Hydroblologla 135: 143-7.

[16] Skelton, P. 2001. Freshwater Fishes of Southern Africa, 2nd ed. South Africa: Struik Publishers (Pty) Ltd.

[17] Talwar, P. K., and Jhingran, A. 1991. Inland Fishes of India and Adjacent Countries. New Delhi: Oxford and IBH Publishing Co. Pvt. Ltd.

[18] Thomas, E. C. 2007. "Comparison of the Performance of Two Tilapia Species, Oreochromi andersonii (Kafue Bream) and O. niloticus (Nile Tilapia-Imported) under Farm Conditions in Zambia.”

[19] Witte, F., Goldschmidt, T., Wanink, J., Oijen, M. V., Goudswaard, K., Witte-Maas, E., and Bouton, N. 1992. "The Destruction of an Endemic Species Flock: Quantitative Data on the Decline of Haplochromine Cichlids of Lake Victoria." Environmental Biology of Fishes 34: 1-28. 